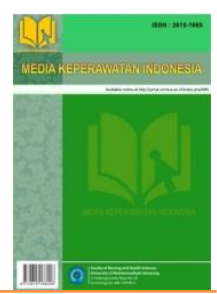

Research article

\title{
Status Breast condition and Babies Health Influence Practice of Exclusive Breastfeeding
}

\author{
Kistina Marieta Baby Soloํ, Regina Vidya Trias Novita²
}

1,2 Sekolah Tinggi Ilmu Kesehatan Sint Carolus, Jakarta

\section{Article Info}

Article History:

Accepted Oct 9th, 2020

\section{Keywords:}

Breastfeeding practice;

Breast condition; babies

health Support

\section{PENDAHULUAN}

ASI merupakan makanan paling sempurna dimana kandungan gizinya yang sesuai kebutuhan bayi untuk pertumbuhan dan perkembangan yang optimal serta ASI mengandung unsur yang dapat melindungi, meningkatkan kesehatan bayi. Di Indonesia target pemerintah mengenai program pemberian ASI eksklusif sampai 6 bulan adalah $80 \%$. Namun, sejauh ini pencapaian cakupan pemberian ASI eksklusif masih jauh dari target yang diharapkan secara nasional (Kemenkes RI, 2014). Cakupan pemberian ASI ekslusif tertinggi adalah provinsi Nusa Tenggara Barat (54,3 \%) dan terendah adalah provinsi Maluku (25,2\%) sedangkan cakupan provinsi Nusa Tenggara Timur yaitu sebesar 77,4 \% (Kemenkes, 2015). Data cakupan pemberian ASI ekslusif di Puskesmas Alak tahun 2013 adalah 49,1 \% dan tahun 2014 sebesar 66,6 \% (Dinas Kesehatan Kota Kupang, 2014, 2015). Cakupan tahun 2015 mengalami penurunan 3,1\% dari tahun 2014 yaitu sebesar 63,5\%. Angka ini masih belum memenuhi target yang ditetapkan oleh Dinas Kesehatan Kota Kupang yaitu sebesar 80\% (Puskesmas Alak, 2015)

Corresponding author:

Kistina Marieta Baby Solo

kristinambsolo@gmail.com

Media Keperawatan Indonesia, Vol 3 No 3, October 2020

e-ISSN: 2615-1669

ISSN: 2722-2802

DOI: https://doi.org/10.26714/mki.3.3.2020.144-149 
Cakupan pemberian ASI ekslusif yang masih rendah disebabkan antara lain kondisi bayi: bayi premature dan bayi kecil, bayi dengan icterus, bayi dengan bibir sumbing, bayi yang menderita penyakit tertentu (Kementrian Kesehatan RI, 2010) dan kondisi ibu baik fisik maupun psikis (pembengkakan, abses payudara, cemas/kurang percaya diri, ibu bekerja, usia, paritas, pengalamanan gagal menyusui, pengetahuan ibu, terlambatnya inisiasi menyusui dini (IMD), dukungan keluarga, faktor sosial budaya dan petugas kesehatan, kurangnya informasi dan pendidikan laktasi saat prenatal dan kebijakan rumah sakit yang kurang mendukung laktasi (Agam \& Syam, 2013). Wilayah tempat tinggal dan penolong persalinan juga berhubungan dengan praktik pemberian ASI eksklusif (Hermina et al., 2012). Pengetahuan ibu secara signifikan memberi dampak pada perilaku ibu dalam memberikan ASI Eksklusif kepada bayinya (Sriningsih, 2011). Penelitian tersebut didukung oleh (Widiyanto et al., 2012), dimana pendidikan ibu pun secara signifikan berhubungan dengan perilaku pemberian ASI Eksklusif

Upaya peningkatan cakupan ASI Eksklusif salah satunya adalah sepuluh langkah menuju keberhasilan menyusui (10 LMKM) yang dicanangkan oleh badan World Health Organization (WHO) dalam hal ini United Nations Children's Fund (UNICEF, 2012). 10 LMKM ini bertujuan untuk melindungi, mempromosikan dan mendukung keberhasilan menyusui baik yang berdampak meningkatnya cakupan pemberian ASI Eksklusif di tingkat nasional maupun internasional (Kudarti et al., 2015). Fenomena tersebut diatas menunjukkan bahwa ada beberapa fakta yang menunjukan bahwa ada banyak faktor yang mempengaruhi perilaku ibu dalam pemberian ASI ekslusif pada bayi. Oleh karena itu perlu diketahui secara pasti faktor-faktor apa saja yang yang membantu ibu dapat memberikan ASI nya secara eksklusif.

\section{METODE}

Metode penelitian bersifat kuantitatif dengan desain deskriptif korelasi dengan rancangan penelitian berupa retrospektif. Pada rancangan penelitian retrospektif dimana mencari hubungan berdasarkan perjalanan waktu ke belakang antara variabel bebas (karakteristik ibu : Pengetahuan ibu, dukungan keluarga, dukungan tenaga kesehatan, dukungan budaya, kondisi payudara ibu, dan kondisi bayi) dan variabel terikat (kejadian pemberian ASI Eksklusif).

Penelitian dilakukan di 32 posyandu daerah binaan Puskesmas Alak Kota Kupang, NTT, pada bulan Agustus-September 2016. Pada penelitian ini menggunakan teknik purposive sampling dengan jumlah sample sebanyak 275 responden. Adapun kriteria inklusi yaitu Ibu yang mempunyai bayi usia 6-12 bulan yang tinggal di wilayah kerja Puskesmas Alak, berkunjung ke posyandu, menyusui esklusif dan non eksklusif. Kriteria eksklusi yaitu tidak bisa membaca dan berbahasa Indonesia.

Alat pengumpul data yang digunakan adalah kuesioner dengan metode angket dimana responden mengisi sendiri pertanyaan yang ada di kuesioner. Penelitian ini setelah mendapatkan ijin penelitian dari pendidikan dan daerah setempat, kemudiaan tahap selanjutnya adalah uji validitas kuesioner. Kuesioner melalui tahap uji validitas dan reliabilitas pada 30 responden di tiga posyandu. Uji valid didapatkan nilai $r$ tabel dari masingmasing variabel antara lain : pengetahuan ( $\mathrm{r}$ tabel 0,257), dukungan keluarga ( $\mathrm{r}$ tabel 0,441 ), dukungan tenaga kesehatan ( $r$ tabel 0,34 ) dan dukungan budaya ( $r$ tabel 0,55 ) dan hasil uji reliabilitas kuesioner didapatkan nilai Alpha Cronbach untuk variabel pengetahuan 0,702, dukungan keluarga 0,723, dukungan tenaga kesehatan 0,737 dan dukungan budaya 0,753.

Hasil dari kuesioner yang telah disebar kemudian dilakukan analisis. Analisis 
statistik yang digunakan adalah uji statistic yaitu uji Chi Square untuk mengetahui hubungan dan melakukan uji pada satu, dua atau lebih sampel/variabel dengan bentuk masing-masing kategori dengan nilai alpha 0,05. Kemudian mencari keeratan dari setiap variable yang berhubungan dengan odds ratio.

\section{HASIL}

Hasil penelitian menunjukkan bahwa responden pada penelitian didominasi oleh ibu berusia 20-35 tahun, dengan pengetahuan yang baik tentang menyusui. Dukungan dari tenaga kesehatan yang diterima oleh responden membuat ibu mampu menyusui secara eksklusif.
Pemberian ASI eksklusif juga didukung oleh tidak adanya masalah pada payudara ibu.

Hasil penelitian menunjukkan bahwa ada hubungan bermakna dengan pemberian ASI eksklusif. (CI95\%=2,108) yang berarti bahwa pekerjaan berpengaruh sebesar 2 kali lipat terhadap perberian ASI Eksklusif. Hasil penelitian menunjukkan Ada hubungan kondisi payudara dengan pemberian ASI Ekslusif (CI95\%=16,50) yang berarti bahwa kondisi payudara ibu berpengaruh sebesar 16,5 kali lipat terhadap perberian ASI Eksklusif. Ada hubungan kondisi kesehatan bayi dengan pemberian ASI Ekslusif (CI95\%=15,45) yang berarti bahwa kesehatan bayi berpengaruh sebesar 15,45 kali lipat terhadap perberian ASI Eksklusif.

Tabel 1

Hubungan Antara Usia, Pengetahuan, Dukungan, Pekerjaan, Kondisi Payudara dan Kondisi Bayi dengan Pemberian ASI ibu

\begin{tabular}{|c|c|c|c|c|c|}
\hline \multirow{3}{*}{ Indikator } & \multicolumn{4}{|c|}{ Pemberian ASI } & \multirow{3}{*}{$p$} \\
\hline & \multicolumn{2}{|c|}{ Eksklusif } & \multicolumn{2}{|c|}{ Non Eksklusif } & \\
\hline & $\mathrm{f}$ & $\%$ & $\mathrm{f}$ & $\%$ & \\
\hline \multicolumn{5}{|l|}{ Usia } & \multirow{4}{*}{0.884} \\
\hline$<20$ tahun & 3 & 60.0 & 2 & 40.0 & \\
\hline 20-35 tahun & 147 & 60.5 & 96 & 39.5 & \\
\hline$>35$ tahun & 15 & 55.6 & 12 & 44.4 & \\
\hline \multicolumn{5}{|l|}{ Dukungan Nakes } & \multirow{3}{*}{0.431} \\
\hline Positif & 86 & 62.3 & 52 & 37.7 & \\
\hline Negatif & 79 & 57.7 & 58 & 42.3 & \\
\hline \multicolumn{5}{|l|}{ Dukungan Keluarga } & \multirow{3}{*}{0.586} \\
\hline Positif & 94 & 51.9 & 59 & 48.1 & \\
\hline Negatif & 71 & 58.2 & 51 & 41.8 & \\
\hline \multicolumn{5}{|l|}{ Pengetahuan } & \multirow{4}{*}{0.234} \\
\hline Baik & 88 & 64.2 & 49 & 32.8 & \\
\hline Cukup & 63 & 57.8 & 17 & 42.2 & \\
\hline Kurang & 14 & 48.3 & 3 & 51.7 & \\
\hline \multicolumn{5}{|l|}{ Pekerjaan } & \multirow{3}{*}{0.036} \\
\hline Tidak Bekerja & 42 & 50.6 & 41 & 49.4 & \\
\hline Bekerja & 123 & 64.1 & 69 & 35.9 & \\
\hline \multicolumn{5}{|l|}{ Kondisi Payudara } & \multirow{3}{*}{0.002} \\
\hline Tidak bermasalah & 149 & 63.9 & 84 & 36.1 & \\
\hline Ada masalah & 35 & 38.1 & 40 & 61.9 & \\
\hline \multicolumn{5}{|l|}{ Kondisi Bayi } & \multirow{3}{*}{0.006} \\
\hline Sehat & 130 & 65.0 & 70 & 35.0 & \\
\hline Sakit & 35 & 46.7 & 40 & 53.3 & \\
\hline
\end{tabular}




\section{PEMBAHASAN}

Hasil penelitian menunjukkan bahwa terdapat hubungan yang bermakna antara pekerjaan ibu ada hubungan bermakna dengan pemberian ASI eksklusif. Hal ini sejalan dengan hasil penelitian Bakti (2016) dimana ada hubungan antara jenis pekerjaan dengan pemberian ASI eksklusif. Ibu yang bekerja memiliki waktu yang relative singkat untuk menyusui dibandingkan dengan ibu yang tidak bekerja. Ibu yang bekerja umumnya mengalami kesulitan dalam membagi waktu dikarenakan oleh beban kerja yang tinggi, stress, dan kenyakinan bahwa ibu mampu memberikan ASI kepada bayinya merupakan faktor yang dapat menghambat keberhasilan ibu dalam memberikan ASI ekslusif (Kurniawan, 2013). Penelitian Lestari (2013) menyimpulkan bahwa motivasi ekstrinsik mempengaruhi ibu yang bekerja untuk menyusui secara eksklusif. Adanya nilai kepercayaan dalam keluarga dan masyarakat merupakan salah satu motivasi ibu untuk memberikan ASI kepada bayinya. Nilai kepercayaan yang baik akan mempengaruhi perilaku ibu dalam memberikan ASI eksklusif, sebaliknya jika nilai kepercayaan yang dianut menyimpang maka perilaku pemberian ASI pun akan menyimpang.

Penelitian ini tidak sejalan dengan penelitian Josefa, K. G. \& Margawati (2011) dimana tidak terdapat hubungan antara pekerjaan dan pemberian ASI Eksklusif. Ibu yang bekerja maupun tidak bekerja sama sama tidak memberikan ASI eksklusif kepada bayinya, hal ini dikarenakan ibu merasa bahwa ASI-nya tidak mencukupi kebutuhan bayi sehingga mereka cenderung memberikan MP-ASI kepada bayinya. Ibu yang bekerja juga memiliki keterbatasan waktu untuk menyusui bayinya lebih sering, hal ini kemungkinan terjadi karena ibu lebih banyak menghabiskan waktu diluar rumah untuk bekerja dan belum adanya fasilita khusus di tempat kerja yang memungkinkan ibu untuk memberi ASI maupun untuk memerah ASInya sehingga ibu akan memilih memberikan MP-ASI kepada bayinya. Masih ada tempat kerja yang tidak memiliki ruangan khusus untuk ibu menyusui sehingga ibu yang bekerja tidak mempunyai kesempatan untuk menyusui bayinya atau untuk sekedar memerah ASInya (Sriningsih, 2011). Peneliti berpendapat bahwa adanya hubungan antara pekerjaan ibu dengan kejadian pemberian ASI eksklusif di Puskesmas Alak kemungkinan didukung oleh tingginya toleransi yang diberikan oleh lingkungan kerja terhadap ibu yang masih menyusui sehingga ibu mendapat kesempatan berupa kompensasi waktu khusus untuk menyusui bayinya selama jam kerja. Hal ini memungkinkan ibu untuk dapat memberikan ASI kepada bayinya sesering atau memerah ASI nya saat sedang bekerja sehingga mungkin ibu bekerja untuk dapat memberikan ASI eksklusif kepada bayinya.

Durasi menyusui berhubungan dengan faktor psikologis, termasuk kepercayaan diri selama menyusui, yakin akan kualitas ASI, kesempatan menyusui dan kekhawatiran selama menyusui (Otsuka et al., 2008), serta kemampuan ibu untuk mengatasi kesulitan menyusui seperti masalah fisik misalnya nyeri, bengkak, lecet pada putting, dan infeksi (El-Gilany \& Abdel-Hady, 2014) akan mempengaruhi keputusan ibu untuk melanjutkan atau menghentikan pemberian ASI eksklusif (Atabik, 2014).

Hasil penelitian menunjukkan Ada hubungan kondisi payudara dengan pemberian ASI Ekslusif. Masalah kondisi payudara ini dapat dicegah dengan mengoreksi posisi ibu selama menyusui dengan memperhatikan perlekatan mulut bayi ke payudara ibu sehingga bayi dapat menyusu dengan nyaman (Hanretty. K, P, 2010 \& Arismawati \& Effendy, 2014). Penelitian Scholichah (2012) dan Zakaria (2014) menjelaskan perawatan payudara merupakan solusi untuk mencegah masalah pada payudara sehingga dapat 
memperlancar pengeluaran atau pancaran ASI.

Peneliti berpendapat bahwa kondisi payudara ibu menentukan keberhasilan ibu dalam pemberian ASI eksklusif kepada bayinya. Ibu dengan payudara yang sehat dan tidak memiliki masalah memiliki tingkat keberhasilan menyusui lebih baik dibandingkan ibu yang memiliki masalah pada payudaranya. Ibu semakin percaya diri dalam menyusui bayinya sehingga produksi dan pengeluaran ASI lebih optimal dimana ditunjukkan bayi mendapat cukup ASI sesuai dengan kebutuhan bayi dengan kenaikan berat badan secara bertahap.

Hasil penelitian menunjukkan bahwa terdapat hubungan kondisi kesehatan bayi dengan pemberian ASI Ekslusif. Ibu akan berhenti memberikan ASI pada bayinya dikarenakan bayinya sakit dan perlu mendapatkan pengobatan (Odom et al., 2013). Ibu cenderung memberikan kombinasi ASI dan formula saat bayinya sakit. Ibu yang memiliki bayi yang sakit cenderung memiliki perasaan cemas karena merasa bersalah, sedih dan takut saat menyentuh dan menggendong bayinya serta memikirkan apakah mampu menyusui bayinya dengan baik. Perasaan ibu inilah yang dapat menghambat proses menyusui (Choiriyah et al., 2015).

Peneliti berpendapat bahwa kondisi bayi dapat mempengaruhi berhasil tidaknya proses menyusui secara eksklusif. Bayi yang sehat memiliki peluang lebih besar untuk mendapatkan ASI secara eksklusif dikarenakan ibu tidak mengalami kecemasan karena anaknya tidak sakit sehingga produksi ASI menjadi lancar, sedangkan bayi yang sakit baik dirawat inap maupun tidak dirawat inap dapat mempengaruhi psikologi ibu dimana ibu akan merasa cemas dengan kondisi bayinya sehingga dapat mempengaruhi produksi hormon prolaktin dan oksitoxin sehingga produksi dan pengeluaran ASI menjadi terhambat. Petugas kesehatan sangat berperan dalam kondisi ini dimana kurangnya pengetahuan dan keterlibatan tenaga kesehatan dalam memberikan informasi tentang pemberian ASI selama bayi sakit merupakan faktor yang mendukung sehingga ibu memutuskan untuk memberikan MP-ASI selama bayi sakit. Informasi yang benar akan membantu ibu untuk tetap memberikan ASI kepada bayinya walaupun bayi dalam keadaan sakit.

\section{SIMPULAN}

Kompetensi petugas kesehatan sangat berperan dalam ketrampilan dalam membantu ibu menyusui dan memberikan infromasi dimana seringnya ibu menyusui mendapatkan informasi yang tidak konsisten sehingga mempengaruhi pengetahuan ibu. Kondisi kesehatan bayi, kondisi payudara dan ibu bekerja merupakan faktor yang sangat mendukung ibu dalam pemberian ASI eksklusif. Informasi yang benar dan pendampingan ibu menyusui serta solusi yang diberikan akan membantu ibu percaya diri untuk tetap memberikan ASI kepada bayinya walaupun ibu memiliki masalah pada payudara dan bayi dalam keadaan sakit.

\section{UCAPAN TERIMAKASIH}

Peneliti mengucapkan terima kasih kepada semua responden yang telah terlibat. Dinas Kesehatan dan PKM Alak Kota Kupang, NTT, untuk dukungan dimana telah memberikan ijin melakukan penelitian.

\section{REFERENSI}

Agam, I. \&, \& Syam, A. (2013). Faktor-faktor yang Mempengaruhi Pemberian ASI Eksklusif di Kelurahan Tamamaung Kecamatan Panakkukang Kota Makassar.

Arismawati, D. F., \& Effendy, H. V. (2014). Hubungan Teknik Menyusui yang Benar dengan Tingkat Keberhasilan Laktasi. Jurnal Keperawatan \& Kebidanan. https://doi.org/10.1051/0004$6361 / 201322771$

Atabik, A. (2014). Faktor Ibu Yang Berhubungan Dengan Praktik Pemberian ASI Ekklusif Di Wilayah Kerja Puskesmas Pamotan. Unnes 
Journal of Public Health., 3(1). https://doi.org/10.15294/ujph.v3i1.3534

Bakti, I., Sarbini, D., Kes, M., Rakhma, L. R., Gz, S., \&, \& Gizi, M. (2016). Hubungan Status Pekerjaan, Pendidikan Formal Dan Pengetahuan Ibu Dengan Pemberian ASI Eksklusif Pada Balita Di Posyandu Lestari, Kelurahan Kumpulrejo Kec. Argomulyo, Salatiga. Doctoral Dissertation, Universitas Muhammadiyah Surakarta.

Choiriyah, M., Hapsari, E. D., \& Lismidiati, W. (2015). Tradisi dan Lingkungan Sosial Memengaruhi Dukungan Menyusui pada Bayi Berat Badan Lahir Rendah di Kota Malang. Kesmas: National Public Health Journal. https://doi.org/10.21109/kesmas.v10i1.816

Dinas Kesehatan Kota Kupang. (2014). Profil Kesehatan Kota Kupang Tahun 2013.

Dinas Kesehatan Kota Kupang. (2015). Profil Kesehatan Kota Kupang Tahun 2014.

El-Gilany, A. H., \& Abdel-Hady, D. M. (2014). Newborn first feed and prelacteal feeds in Mansoura, Egypt. BioMed Research International. https://doi.org/10.1155/2014/258470

Hanretty. K, P. (2010). Ilustrasi Obstetri Edisi VII. Churchill Livingstone.

Hermina, H., Fuada, N., \&, \& Hidayat, T. S. (2012). Faktor Informasi ASI Dan MP-ASI Kaitannya Dengan Praktik Pemberian ASI-Eksklusif Di Provinsi Nusa Tenggara Timur (Studi di Kota Kupang dan Kabupaten Kupang). Bulletin of Health Research. https://doi.org/10.22435/bpk.v39i1Mar.76.2 $2-33$

Josefa, K. G., \&, \& Margawati, A. (2011). Faktor-Faktor yang Mempengaruhi Perilaku Pemberian ASI eksklusif pada Ibu (Studi Kasus DI wilayah Kerja Puskesmas Manyaran, Kecamatan Semarang Barat). Doctoral Dissertation, Faculty of Medicine.

Kemenkes, R. (2015). Profil Kesehatan RI 2015. In Profil Kesehatan Indonesia Tahun 2015. https://doi.org/10.1111/evo.12990

Kemenkes RI. (2014). Profil Kesehatan Indonesia (Demografi). In Kementerian Kesehatan Republik

Indonesia.

https://doi.org/10.1037/0022-

3514.51.6.1173

Kementrian Kesehatan RI. (2010). Buku saku Pelayanan Kesehatan Neonatus Esensial: Pedoman teknis pelayanan kesehatan dasar. Kementerian Kesehatan RI.

Kudarti, K., Kartasurya, M. I. \&, \& Pradigdo, S. F. (2015). Difference Analysis of the Implementation of Ten Steps to Successful
Breastfeeding between Private and Public Hospitals in District of Kudus. Jurnal Manajemen Kesehatan Indonesia, 3, 3.

Kurniawan, B. (2013). Determinan Keberhasilan Pemberian Air Susu Ibu Eksklusif. Jurnal Kedokteran Brawijaya. https://doi.org/10.21776/ub.jkb.2013.027.04 .11

Lestari, D., Zuraida, R., \& Larasati, T. (2013). Hubungan Tingkat Pengetahuan Ibu tentang Air Susu Ibu dan Pekerjaan Ibu dengan Pemberian ASI Eksklusif di Kelurahan Fajar Bulan. Medical Journal of Lampung University.

Odom, E. C., Li, R., Scanlon, K. S., Perrine, C. G., \& Grummer-Strawn, L. (2013). Reasons for earlier than desired cessation of breastfeeding. Pediatrics. https://doi.org/10.1542/peds.2012-1295

Otsuka, K., Dennis, C. L., Tatsuoka, H., \& Jimba, M. (2008). The relationship between breastfeeding self-efficacy and perceived insufficient milk among Japanese mothers. JOGNN - Journal of Obstetric, Gynecologic, and Neonatal Nursing. https://doi.org/10.1111/j.15526909.2008.00277.x

Puskesmas Alak. (2015). Laporan PWS Gizi Puskesmas Alak.

Scholichah, N. (2012). Hubungan Perawatan Payudara pada Ibu Postpartum dengan Kelancaran Pengeluaran ASI di Desa Karang Duren Kecamatan Tengaran Kabupaten Semarang. Jurnal Komunikasi Kesehatan, 3.

Sriningsih, I. (2011). Faktor Demografi, Pengetahuan Ibu Tentang Air Susu Ibu dan Pemberian Asi Eksklusif. KEMAS: Jurnal Kesehatan Masyarakat.

UNICEF. (2012). Ringkasan Kajian Kesehatan Ibu dan Anak.

Widiyanto, S., Aviyanti, D., \& A, M. T. (2012). Hubungan Pendidikan dan Pengetahuan Ibu tentang ASI Eksklusif dengan Sikap terhadap Pemberian ASI Eksklusif Subur. Jurnal Kedokteran Muhammadiyah. https://doi.org/10.4039/Ent111111-1

Zakaria, R. (2014). Faktor-faktor yang Berhubungan dengan Tindakan Ibu dalam Pemberian ASI eksklusif di Wilayah Kerja Puskesmas Tilongkabila Kabupaten Bone Bolango Tahun 2014. Artikel Penelitian. 